\title{
Analisis Pengaruh Tegangan Tidak Seimbang pada Kinerja Motor Induksi Menggunakan Metode Transformasi Direct Qudrature
}

\author{
Paulus Setiawan \\ Departemen Aeronautika, Sekolah Tinggi Teknologi Adisutjipto, Yogyakarta \\ email: paulussetiawanstta@gmail.com
}

\begin{abstract}
Induction motors are one type of electric motors that work based on electromagnetic induction. The problem that often arises lately is the occurrence of voltage imbalances. Unbalanced voltage is a voltage value that is not the same in a three-phase voltage system contained in the electrical power system. On the basis of these problems, it is necessary to conduct research that can analyze the dynamics of the performance of an induction motor. Dynamic analysis is done by modeling a three-phase induction motor using an arbitrary reference frame with the direct qudrature transformation method in Matlab/Simulink. In studies with voltage imbalances up to 5\%, electromagnetic torque has decreased by $2.89 \%$ to $13.83 \%$ and stator current in one phase has increased by $29.1 \%$ to $245.8 \%$.
\end{abstract}

Keywords - dq0 transformation, Matlab/Simulik, reference frame arbitrary, three phase induction motor, unbalanced voltage.

\section{Pendahuluan}

Motor induksi adalah salah satu jenis dari motor-motor listrik yang bekerja berdasarkan induksi elektromagnetik. Motor induksi memiliki sebuah sumber energi listrik yaitu di sisi stator, sedangkan sistem kelistrikan di sisi rotornya diinduksikan melalui celah udara dari stator dengan media elektromagnet, sehingga hal inilah yang dapat menyebabkan motor tersebut diberi nama motor induksi. Adapun penggunaan motor induksi di industri adalah sebagai penggerak blower, kompresor, pompa, penggerak utama proses produksi atau mill, dan lain sebagainya.

Permasalahan yang sering muncul belakangan ini adalah terjadinya ketidakseimbangan tegangan. Tegangan tidak seimbang adalah suatu nilai tegangan yang tidak sama pada sistem tegangan tiga fasa yang terdapat dalam sistem distribusi daya listrik. Tegangan yang tidak seimbang tersebut dapat menyebabkan masalah serius pada motor induksi [1-3] dan perangkat induktif lainnya. Selain masalah tersebut, ketidakseimbangan tegangan juga dapat menyebabkan arus pada motor induksi menjadi tidak seimbang dan mengalami kenaikan beberapa kali, dan juga dapat memberikan efek pemanasan kepada motor sehingga efisiensi motor induksi menjadi turun.

Atas dasar permasalahan tersebut, perlu dilakukan penelitian yang dapat menganalisis dinamika kinerja motor induksi. Analisis dinamik dilakukan dengan memodelkan motor induksi tiga fasa menggunakan kerangka acuan arbitrary. Dalam kerangka acuan tersebut, metode yang digunakan adalah metode transfomasi direct qudrature. Metode transformasi direct qudrature adalah metode transformasi yang mengubah dari sistem tiga fasa $a b c$ ke bentuk sistem dua fasa dengan konfigurasi dq0 [5-12], sebagai tujuan untuk memudahkan perhitungan parameter-parameter dan komponen dari suatu motor induksi yang kemudian disimulasikan dengan Matlab Simulink. Untuk hasil luaran yang akan dicapai adalah dapat menganalisis dan mengetahui karakteristik dari arus stator, arus rotor, torsi elektromagnetik, kecepatan putaran rotor, daya masukan motor, daya keluaran motor, dan efisiensi saat terjadi gangguan tegangan tidak seimbang.

Manuscript submitted 23 August 2019; revised 29 August 2019; accepted 29 August 2019. Published 31 August 2019; http://dx.doi.org/10.28989/avitec.v1i1.507 


\section{Metodologi Penelitian}

\subsection{Transformasi Tegangan Tiga Fasa menjadi Dua Fasa}

Untuk melakukan analisis terhadap mesin induksi diperlukan pengetahuan tentang teori kerangka acuan yang dikenalkan oleh R. H. Park sekitar tahun 1920-an, yang merupakan sebuah pendekatan untuk menganalisis mesin-mesin listrik., yang dikenal dengan Transformasi Park. Transformasi Park mengubah variabel-variabel dari sumbu $a b c$ ke dalam sumbu direct dan quadrature atau yang lebih dikenal dengan sumbu $d q$. Transformasi ini dapat dilukiskan sebagai hubungan trigonometri antara variabel-variabel dalam sumbu abc dengan variabel dalam sumbu $d q[13]$, seperti terlihat dalam Gambar 1.

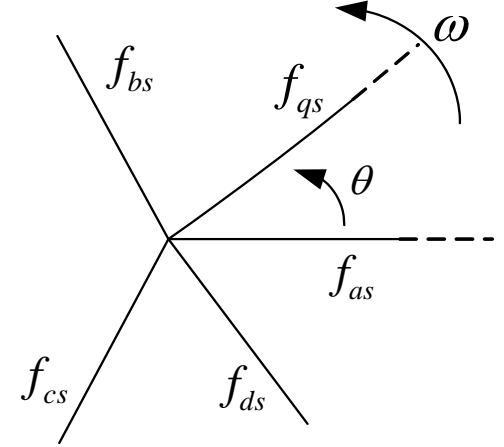

Gambar 1. Skema Transformasi Ekivalen

Persamaan tegangan dalam ragam variabel mesin dapat dituliskan sebagai

$v_{a b c s}=r_{s} i_{a b c s}+p \lambda_{a b c s}$
$v_{a b c r}=r_{r} i_{a b c r}+p \lambda_{a b c r}$

$$
\begin{aligned}
& \text { dimana: } \\
& \left(f_{a b c s}\right)^{T}=\left[\begin{array}{lll}
f_{a s} & f_{b s} & f_{c s}
\end{array}\right] \\
& \left(f_{a b c r}\right)^{T}=\left[\begin{array}{lll}
f_{a r} & f_{b r} & f_{c r}
\end{array}\right]
\end{aligned}
$$

Pada persamaan di atas, subscript $s$ menyatakan parameter dan variabel yang dikelompokkan ke dalam rangkaian stator, dan subscript $r$ menyatakan parameter dan variabel yang dikelompokkan ke dalam rangkaian rotor. Untuk sistem linear magnetik, fluks lingkup dapat dituliskan sebagai

$$
\left[\begin{array}{l}
\lambda_{a b c s} \\
\lambda_{a b c r}
\end{array}\right]=\left[\begin{array}{cc}
L_{s} & L_{s r} \\
\left(L_{s r}\right)^{T} & L_{r}
\end{array}\right]\left[\begin{array}{l}
i_{a b c s} \\
i_{a b c r}
\end{array}\right]
$$

Secara khusus belitan induktansi dapat diturunkan dengan persamaan

$$
\begin{gathered}
L_{s}=\left[\begin{array}{ccc}
L_{l s}+L_{m s} & -\frac{1}{2} L_{m s} & -\frac{1}{2} L_{m s} \\
-\frac{1}{2} L_{m s} & L_{l s}+L_{m s} & -\frac{1}{2} L_{m s} \\
-\frac{1}{2} L_{m s} & -\frac{1}{2} L_{m s} & L_{l s}+L_{m s}
\end{array}\right] \\
L_{r}=\left[\begin{array}{ccc}
L_{l r}+L_{m r} & -\frac{1}{2} L_{m r} & -\frac{1}{2} L_{m r} \\
-\frac{1}{2} L_{m r} & L_{l r}+L_{m r} & -\frac{1}{2} L_{m r} \\
-\frac{1}{2} L_{m r} & -\frac{1}{2} L_{m r} & L_{l r}+L_{m r}
\end{array}\right]
\end{gathered}
$$

$$
L_{s r}=L_{s}\left[\begin{array}{ccc}
\cos \theta_{r} & \cos \left(\theta_{r}+\frac{2 \pi}{3}\right) & \cos \left(\theta_{r}-\frac{2 \pi}{3}\right) \\
\cos \left(\theta_{r}\right) & \cos \theta_{r} & \cos \left(\theta_{r}+\frac{2 \pi}{3}\right) \\
\cos \left(\theta_{r}+\frac{2 \pi}{3}\right) & \cos \left(\theta_{r}-\frac{2 \pi}{3}\right) & \cos \theta_{r}
\end{array}\right]
$$

Dari persamaan (7), didapatkan

$$
L_{r}^{\prime}=\left[\begin{array}{ccc}
L_{l r}{ }_{l r}+L_{m s} & -\frac{1}{2} L_{m s} & -\frac{1}{2} L_{m s} \\
-\frac{1}{2} L_{m s} & L_{l r}^{\prime}+L_{m s} & -\frac{1}{2} L_{m s} \\
-\frac{1}{2} L_{m s} & -\frac{1}{2} L_{m s} & L_{l r}^{\prime}+L_{m s}
\end{array}\right]
$$

Sekarang persamaan fluks lingkup motor dapat diekspresikan

$\left[\begin{array}{c}\lambda_{a b c s} \\ \lambda^{\prime}{ }_{a b c r}\end{array}\right]=\left[\begin{array}{cc}L_{s} & L_{s r}^{\prime} \\ \left(L_{s r}^{\prime}\right)^{T} & L_{r}\end{array}\right]\left[\begin{array}{c}i_{a b c s} \\ i^{\prime}{ }_{a b c r}\end{array}\right]$ 
Dan terminologi persamaan tegangan yang didasarkan pada belitan stator, dapat diekspresikan sebagai

$\left[\begin{array}{c}v_{a b c s} \\ v^{\prime}{ }_{a b c r}\end{array}\right]=\left[\begin{array}{cc}r_{s}+p L_{s} & p L^{\prime}{ }_{s r} \\ p\left(L_{s r}^{\prime}\right)^{T} & r_{r}^{\prime}+p L_{r}^{\prime}\end{array}\right]\left[\begin{array}{c}i_{a b c s} \\ i^{\prime}{ }_{a b c r}\end{array}\right]$

\subsubsection{Persamaan Transformasi Pada Rangkaian Stator}

Perubahan variabel-variabel pada persamaan transformasi tiga fasa dari elemen rangkaian stasioner menjadi kerangka acuan arbitrary dapat dituliskan sebagai

$$
f_{q d 0 s}=K_{s} f_{a b c s}
$$

Di mana

$$
\begin{aligned}
& \left(f_{q d s 0 s}\right)^{T}=\left[\begin{array}{lll}
f_{q s} & f_{d s} & f_{0 s}
\end{array}\right] \\
& \left(f_{a b c s}\right)^{T}=\left[\begin{array}{lll}
f_{a s} & f_{b s} & f_{c s}
\end{array}\right]
\end{aligned}
$$

$$
K_{s}=\frac{2}{3}\left[\begin{array}{ccc}
\cos \theta & \cos \left(\theta-\frac{2 \pi}{3}\right) & \cos \left(\theta+\frac{2 \pi}{3}\right) \\
\sin \theta & \sin \left(\theta-\frac{2 \pi}{3}\right) & \sin \left(\theta+\frac{2 \pi}{3}\right) \\
\frac{1}{2} & \frac{1}{2} & \frac{1}{2}
\end{array}\right]
$$

\subsubsection{Persamaan Transformasi Pada Rangkaian Rotor}

Analisis motor induksi juga ditujukan untuk mentransformasikan variabel-variabel yang dikelompokkan ke dalam belitan rotor. Perubahan variabel-variabel pada persamaan transformasi tiga fasa rangkaian rotor ke kerangka acuan arbitrary dapat dituliskan sebagai

$$
f^{\prime}{ }_{\text {qd } 0 r}=K_{r} f^{\prime}{ }^{\prime}{ }_{b c r}
$$

Di mana

$$
\begin{aligned}
& \left(f^{\prime}{ }_{q d s 0 r}\right)^{T}=\left[\begin{array}{lll}
f^{\prime}{ }_{a r} & f^{\prime}{ }_{d r} & f^{\prime}{ }_{0 r}
\end{array}\right] \\
& \left(f^{\prime}{ }_{a b c r}\right)^{T}=\left[\begin{array}{lll}
f^{\prime}{ }_{a r} & f^{\prime}{ }_{b r} & f^{\prime}{ }_{c r}
\end{array}\right]
\end{aligned}
$$

$$
K_{r}=\frac{2}{3}\left[\begin{array}{ccc}
\cos \beta & \cos \left(\beta-\frac{2 \pi}{3}\right) & \cos \left(\beta+\frac{2 \pi}{3}\right) \\
\sin \beta & \sin \left(\beta-\frac{2 \pi}{3}\right) & \sin \left(\beta+\frac{2 \pi}{3}\right) \\
\frac{1}{2} & \frac{1}{2} & \frac{1}{2}
\end{array}\right]
$$

\subsection{Persamaan Tegangan Dalam Variabel Kerangka Acuan}

Berdasarkan persamaan (12), (13), (14), (16), (17), dan (18), diperoleh persamaan tegangan dan fluks lingkup dalam sumbu $d q$ sebagai

$$
\begin{array}{ll|l}
v_{q d 0 s}=r_{s} i_{q d 0 s}+\omega \lambda_{d q s}+p \lambda_{q d 0 s} & \text { (20) } & \text { Di mana } \\
v_{q d 0 r}^{\prime}=r_{r}^{\prime} i^{\prime}{ }_{q d 0 r}+\left(\omega-\omega_{r}\right) \lambda_{d q r}^{\prime}+p \lambda_{q d 0 r}^{\prime} & (21) & \left(\lambda_{d q s}\right)^{T}=\left[\begin{array}{lll}
\lambda_{d s} & -\lambda_{q s} & 0
\end{array}\right] \\
\left(\lambda_{d q r}^{\prime}\right)^{T}=\left[\begin{array}{lll}
\lambda_{d r}^{\prime} & -\lambda^{\prime}{ }_{q r} & 0
\end{array}\right]
\end{array}
$$

Substitusi persamaan transformasi ke dalam persamaan fluks lingkup yang dituliskan ke dalam variabel $a b c$ pada persamaan (10) sebelumnya, maka persamaan fluks lingkup untuk sistem magnetik sebagai

$$
\begin{aligned}
& {\left[\begin{array}{c}
\lambda_{q d 0 s} \\
\lambda_{q d 0 r}^{\prime}
\end{array}\right]=\left[\begin{array}{cc}
K_{s} L_{s}\left(K_{s}\right)^{-1} & K_{s} L_{s r}^{\prime}\left(K_{r}\right)^{-1} \\
K_{r}\left(L_{s r}^{\prime}\right)^{T}\left(K_{s}\right)^{-1} & K_{r} L_{r}^{\prime}\left(K_{r}\right)^{-1}
\end{array}\right]\left[\begin{array}{c}
i_{q d 0 s} \\
i_{q d 0 r}^{\prime}
\end{array}\right]} \\
& K_{s} L_{s}\left(K_{s}\right)^{-1}=\left[\begin{array}{ccc}
L_{l s}+L_{M} & 0 & 0 \\
0 & L_{l s}+L_{M} & 0 \\
0 & 0 & L_{l s}
\end{array}\right]
\end{aligned}
$$

Di mana, $L_{M}=\frac{3}{2} L_{m s}$
$K_{r} L_{r}^{\prime}\left(K_{r}\right)^{-1}=\left[\begin{array}{ccc}L^{\prime}{ }_{l r}+L_{M} & 0 & 0 \\ 0 & L_{l r}^{\prime}+L_{M} & 0 \\ 0 & 0 & L_{l r}^{\prime}\end{array}\right](27)$
$K_{s} L_{s r}^{\prime}\left(K_{r}\right)^{-1}=K_{r}\left(L_{s r}^{\prime}\right)^{T}\left(K_{s}\right)^{-1}=\left[\begin{array}{ccc}L_{M} & 0 & 0 \\ 0 & L_{M} & 0 \\ 0 & 0 & 0\end{array}\right](28)$ 


\subsection{Pemodelan Motor Induksi}

Analisis dinamik motor induksi biasanya dimodelkan dengan rangkaian ekivalen dalam kerangka acuan. Berdasarkan persamaan (20) dan (21) dapat diturunkan persamaan tegangan motor induksi ke dalam sumbu $d q$ sebagai

$$
\begin{aligned}
& v_{q s}=r_{s} i_{q s}+\omega \lambda_{d s}+p \lambda_{q s} \\
& v_{d s}=r_{s} i_{d s}-\omega \lambda_{q s}+p \lambda_{d s} \\
& v_{0 s}=r_{s} i_{0 s}+p \lambda_{0 s}
\end{aligned}
$$

Dengan mensubstitusi persamaan (25), (27), dan (28) ke dalam persamaan (24), maka untuk persamaan fluks lingkup motor induksi dapat dikembangkan ke dalam bentuk

$$
\begin{aligned}
& \lambda_{q s}=L_{l s} i_{q s}+L_{M}\left(i_{q s}+i^{\prime}{ }_{q r}\right) \\
& \lambda_{d s}=L_{l s} i_{d s}+L_{M}\left(i_{d s}+i_{d r}\right) \\
& \lambda_{0 s}=L_{l s} i_{0 s}
\end{aligned}
$$

$$
\begin{aligned}
& \lambda_{q r}=L_{l r}^{\prime} i^{\prime}{ }_{q r}+L_{M}\left(i_{q s}+i^{\prime}{ }_{q r}\right) \\
& \lambda_{d r}=L^{\prime}{ }_{l r} i_{d r}^{\prime}+L_{M}\left(i_{d s}+i^{\prime}{ }_{d r}\right) \\
& \lambda_{0 r}=L^{\prime}{ }_{l r} i^{\prime}{ }_{0 r}
\end{aligned}
$$

Kemudian rangkaian ekivalen pada persamaan tegangan dan fluks lingkup motor induksi menjadi seperti yang ditunjukkan pada Gambar 2.

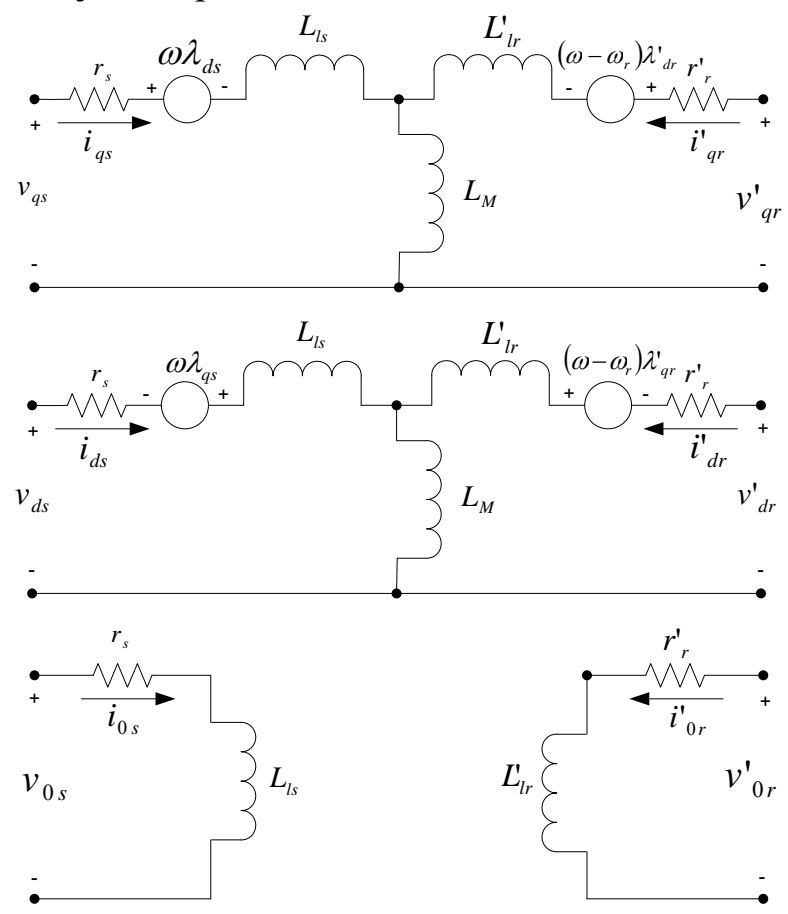

Gambar 2. Pemodelan Motor Induksi dengan Kerangka Acuan

Berdasarkan persamaan (29) sampai dengan (34), persamaan tegangan dan fluks lingkup dalam terminologi atau istilah reaktansi induktif dapat dituliskan sebagai

$$
\begin{aligned}
& v_{q s}=r_{s} i_{q s}+\frac{\omega}{\omega_{b}} \psi_{d s}+\frac{p}{\omega_{b}} \psi_{q s} \\
& v_{d s}=r_{s} i_{d s}-\frac{\omega}{\omega_{b}} \psi_{q s}+\frac{p}{\omega_{b}} \psi_{d s} \\
& v_{0 s}=r_{s} i_{0 s}+\frac{p}{\omega_{b}} \psi_{0 s}
\end{aligned}
$$

$$
\begin{aligned}
& v_{q r}^{\prime}=r_{r}^{\prime} i_{q r}^{\prime}+\left(\frac{\omega-\omega_{r}}{\omega_{b}}\right) \psi_{d r}^{\prime}+\frac{p}{\omega_{b}} \psi_{q r}^{\prime} \\
& v_{d r}^{\prime}=r_{r}^{\prime} i_{d r}^{\prime}-\left(\frac{\omega-\omega_{r}}{\omega_{b}}\right) \psi_{q r}^{\prime}+\frac{p}{\omega_{b}} \psi_{d r}^{\prime} \\
& v_{0 r}^{\prime}=r_{r}^{\prime} i_{0 r}^{\prime}+\frac{p}{\omega_{b}} \psi_{q r}^{\prime}
\end{aligned}
$$


Di mana $\omega_{b}$ adalah kecepatan sudut elektrik yang digunakan untuk mengkomputasi nilai reaktansi induktif. Maka selanjutnya persamaan fluks lingkup (35) sampai dengan (40) menjadi persamaan fluks lingkup dalam satuan unit tegangan per detik yaitu

$$
\begin{aligned}
& \psi_{q s}=X_{l s} i_{q s}+X_{M}\left(i_{q s}+i^{\prime}{ }_{q r}\right) \\
& \psi_{d s}=X_{l s} i_{d s}+X_{M}\left(i_{d s}+i_{d r}\right) \\
& \psi_{0 s}=X_{l s} i_{0 s}
\end{aligned}
$$

$$
\begin{aligned}
& \psi_{q r}^{\prime}=X^{\prime}{ }_{l r} i_{q r}^{\prime}+X_{M}\left(i_{q s}+i_{q r}^{\prime}\right) \\
& \psi_{d r}^{\prime}=X_{l r}^{\prime} i_{d r}^{\prime}+X_{M}\left(i_{d s}+i_{d r}^{\prime}\right) \\
& \psi^{\prime}{ }_{0 r}=X^{\prime}{ }_{l r} i_{0 r}^{\prime}
\end{aligned}
$$

Kemudian persamaan untuk mensimulasikan motor induksi yang simetris dengan kerangka acuan arbitrary, dapat dibuat dengan terlebih dahulu menyelesaikan persamaan fluks lingkup atau persamaan fluks per detik untuk arus. Sehingga dari persamaan (47-52) dapat dituliskan

$$
\begin{aligned}
& i_{q s}=\frac{1}{X_{l s}}\left(\psi_{q s}-\psi_{m q}\right) \\
& i_{d s}=\frac{1}{X_{l s}}\left(\psi_{d s}-\psi_{m d}\right) \\
& i_{0 s}=\frac{1}{X_{l s}} \psi_{0 s}
\end{aligned}
$$

$$
\begin{aligned}
& i_{q r}^{\prime}=\frac{1}{X_{l r}^{\prime}}\left(\psi_{q r}^{\prime}-\psi_{m q}\right) \\
& i_{d r}^{\prime}=\frac{1}{X_{l r}^{\prime}}\left(\psi_{d r}^{\prime}-\psi_{m d}\right) \\
& i_{0 r}^{\prime}=\frac{1}{X_{l r}^{\prime}} \psi_{0 r}^{\prime}
\end{aligned}
$$

Di mana $\psi_{m q}$ dan $\psi_{m d}$, yang berguna saat mewakili saturasi, didefinisikan sebagai

$\psi_{m q}=X_{M}\left(i_{q s}+i_{q r}^{\prime}\right)$
$\psi_{m d}=X_{M}\left(i_{d s}+i_{d r}^{\prime}\right)$

\subsection{Persamaan Torsi Elektromagnetik, Kecepatan Rotor, dan Daya Input}

Persamaan torsi elektromagnetik dalam variabel kerangka acuan arbitrary dapat dituliskan sebagai [13]

$$
\begin{aligned}
& T_{e}=\left(\frac{P}{2}\right)\left[\left(K_{s}\right)^{-1} i_{q d 0 s}\right]^{T} \frac{d}{d \theta_{r}}\left[L_{s r}^{\prime}\right]\left(K_{r}\right)^{-1} i_{q d 0 r}^{\prime} \\
& T_{e}=\left(\frac{3}{2}\right)\left(\frac{P}{2}\right) L_{M}\left(i_{q s} i^{\prime}{ }_{d r}-i_{d s} i^{\prime}{ }_{q r}\right)
\end{aligned}
$$

Persamaan ekivalen dari torsi elektromagnetik lainnya, dapat ditulis sebagai

$$
\begin{aligned}
& T_{e}=\left(\frac{3}{2}\right)\left(\frac{P}{2}\right)\left(\lambda^{\prime}{ }_{q r} i_{d r}^{\prime}-\lambda^{\prime}{ }_{d r} i_{q r}^{\prime}\right) \\
& T_{e}=\left(\frac{3}{2}\right)\left(\frac{P}{2}\right)\left(\lambda_{d s} i_{q s}-\lambda_{q s} i_{d s}\right)
\end{aligned}
$$

Berdasarkan persamaan (55) dan (56), persamaan torsi elektromagnetik dalam fluks lingkup kerangka acuan arbitrary dapat dituliskan sebagai

$$
T_{e}=\left(\frac{3}{2}\right)\left(\frac{P}{2}\right)\left(\frac{1}{\omega_{b}}\right)\left(\psi_{q r}^{\prime} i_{d r}^{\prime}-\psi_{d r}^{\prime} i_{q r}^{\prime}\right)
$$

Hubungan antara torsi elektromagnetik dan kecepatan rotor dapat dituliskan dengan persamaan $T_{e}=2 H \frac{d}{d t} \frac{\omega_{r}}{\omega_{b}}+T_{L}$

$\frac{d \omega_{r}}{d t}=\frac{\omega_{b}}{2 H}\left(T_{e}-T_{L}\right)$ 
Untuk dapat mewakili interpretasi yang berati dalam pemodelan, analisis, dan simulasi, maka daya input untuk motor tiga fasa harus sama dengan daya input pada mesin dua fasa [14]. Sehingga persamaan daya input dapat dinyatakan dengan

$$
p_{i}=\frac{3}{2}\left(v_{q s} i_{q s}+v_{d s} i_{d s}\right)
$$

\subsection{Definisi Tegangan Tidak Seimbang}

Ada berbagai definisi ketidakseimbangan tegangan dan [4] menegaskan bahwa ada kebutuhan untuk memahami implikasinya menggunakan salah satu definisi, karena ada sedikit variasi antara persentase ketidakseimbangan yang diperoleh menggunakan dua metode yang berbeda untuk rangkaian tegangan yang sama. Perbedaan ini menjadi signifikan untuk tingkat ketidakseimbangan yang tinggi ketika definisi NEMA digunakan. Menurut [3, 4] ketidakseimbangan tegangan dapat definisikan sebagai:

a) NEMA

Asosiasi Produsen Listrik Nasional dan Standar Generator (NEMA MG1.1993) mendefinisikannya, dalam hal Line Voltage Unbalanced in Percentage (LVUP) pada terminal mesin listrik sebagai

$$
\begin{aligned}
& L V U P=\frac{(\text { max imum_voltage_deviation_from_average_line_voltage })}{(\text { average_line_voltage_magnitude })} \times 100 \% \\
& L V U P=\frac{\operatorname{Max}\left[\left|V_{a b}-V_{L a v g}\right|,\left|V_{b c}-V_{\text {Lavg }}\right|,\left|V_{c a}-V_{L a v g}\right|\right]}{V_{\text {Lavg }}} \times 100 \% \\
& \operatorname{dimana} V_{L a v g}=\frac{\left(V_{a b}+V_{b c}+V_{c a}\right)}{3}
\end{aligned}
$$

b) IEEE

IEEE std 141, mendifinisikan Phase Voltage Unbalanced in Percentage (PVUR) pada terminal mesin. Ketidakseimbangan tegangan fasa dalam persentase PVUR didefinisikan sebagai

$$
\begin{aligned}
& P V U R=\frac{M a x\left[\left|V_{a}-V_{\text {pavg }}\right|,\left|V_{b}-V_{\text {pavg }}\right|,\left|V_{c}-V_{\text {pavg }}\right|\right]}{V_{\text {pavg }}} \times 100 \% \\
& \operatorname{dimana} V_{\text {Pavg }}=\frac{\left(V_{a}+V_{b}+V_{c}\right)}{3}
\end{aligned}
$$




\section{Hasil Penelitian dan Analisis}

3.1 Perancangan dengan simulasi
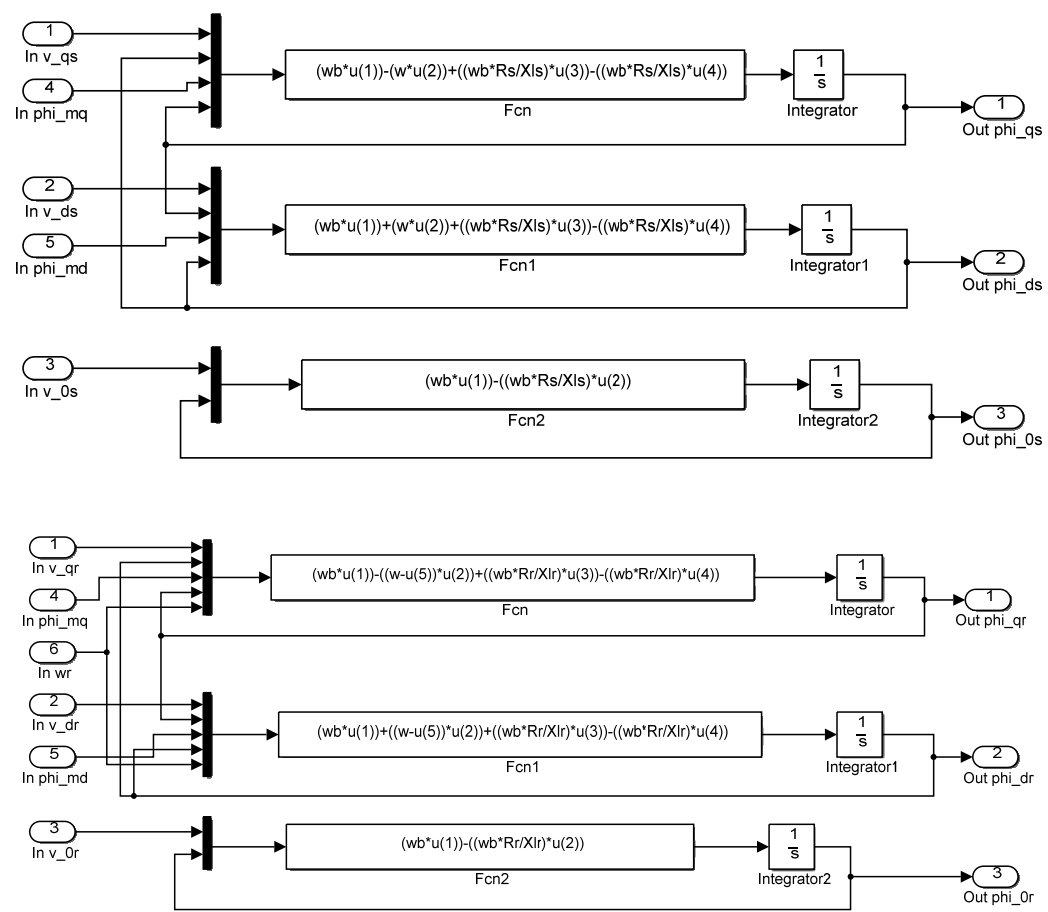

Gambar 3. Implementasi Fluks Lingkup pada

Stator dan Rotor

Pada bagian ini, motor induksi tiga fasa dimodelkan dan kemudian disimulasikan dengan Matlab / Simulink. Pemodelan diimplementasikan dengan persamaan-persamaan yang telah dituliskan pada bagian ke-2 metodologi penelitian. Dalam pemodelan ini, simulasi dimulai dengan menghasilkan tegangan stator tiga fasa yang sesuai dengan persamaan (1-28), dan kemudian mengubah tegangan seimbang ini menjadi tegangan dua fasa yang dirujuk pada kerangka acuan secara sinkron menggunakan transformasi $d q 0$ seperti pada persamaan (29-34). Setelah itu, hubungan fluks lingkup dq0 pada persamaan (35-46) diimplementasikan seperti yang ditunjukkan pada Gambar 3.
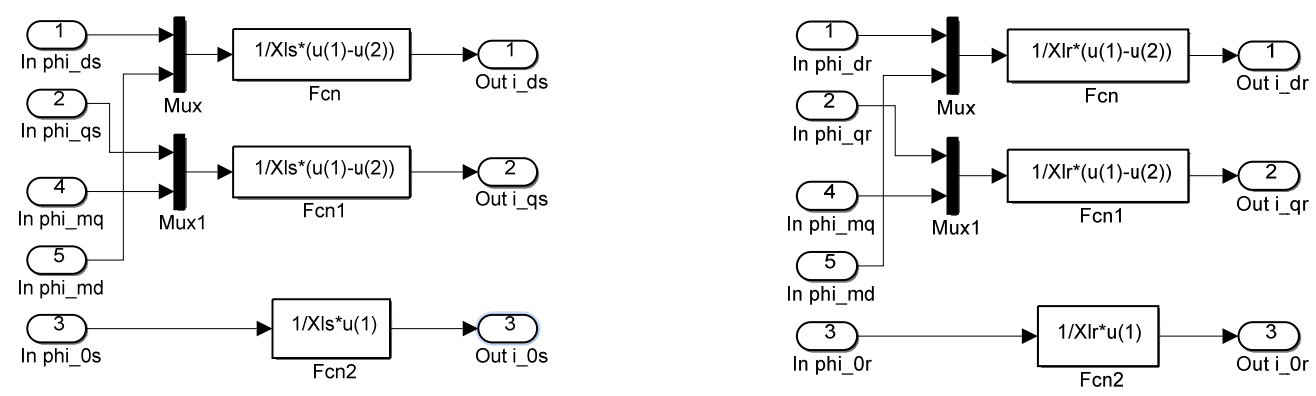

Gambar 4. Implementasi Kalkulasi pada Arus $i_{q s}, i_{d s}, i_{q r}, i_{d r}$

Pada Gambar 4., menunjukkan blok Simulink yang digunakan untuk menghitung arus $i_{q s}, i_{d s}, i_{q r}, i_{d r}$ sesuai dengan persamaan (53-58), dan menghitung $\lambda_{m q}, \lambda_{m d}$ seperti pada persamaan $(59,60)$. 

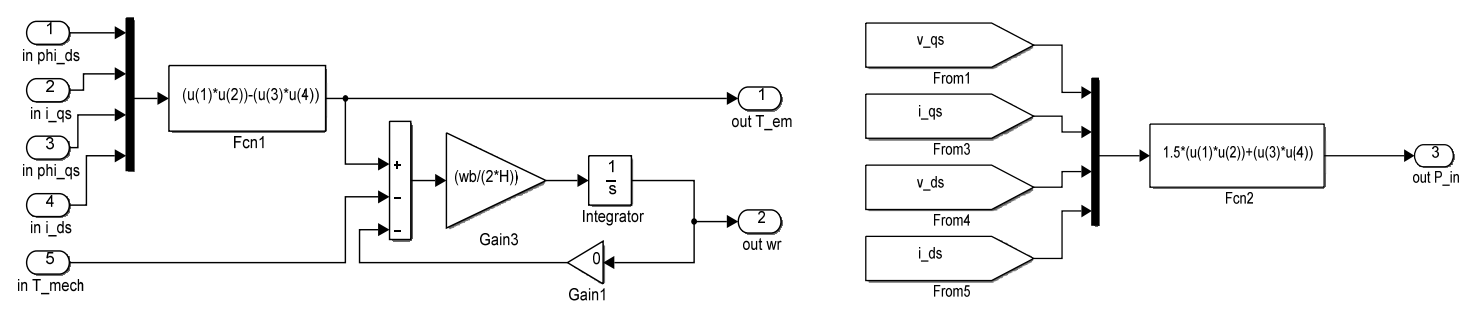

Gambar 5. Implementasi Kalkulasi pada Torsi Elektromagnetik, Kecepatan Rotor, dan Daya input

Pada Gambar 5., menunjukkan blok Simulink yang digunakan untuk menghitung torsi elektromagnetik $T_{e}$ dan kecepatan rotor $\omega_{r}$ sesuai dengan persamaan (61-67), serta untuk menghitung daya input $p_{i}$ seperti pada persamaan (68). Sehingga pada Gambar 6., menunjukkan pemodelan simulink secara lengkap yang dapat digunakan untuk menganalisis dinamika motor induksi tiga fasa.

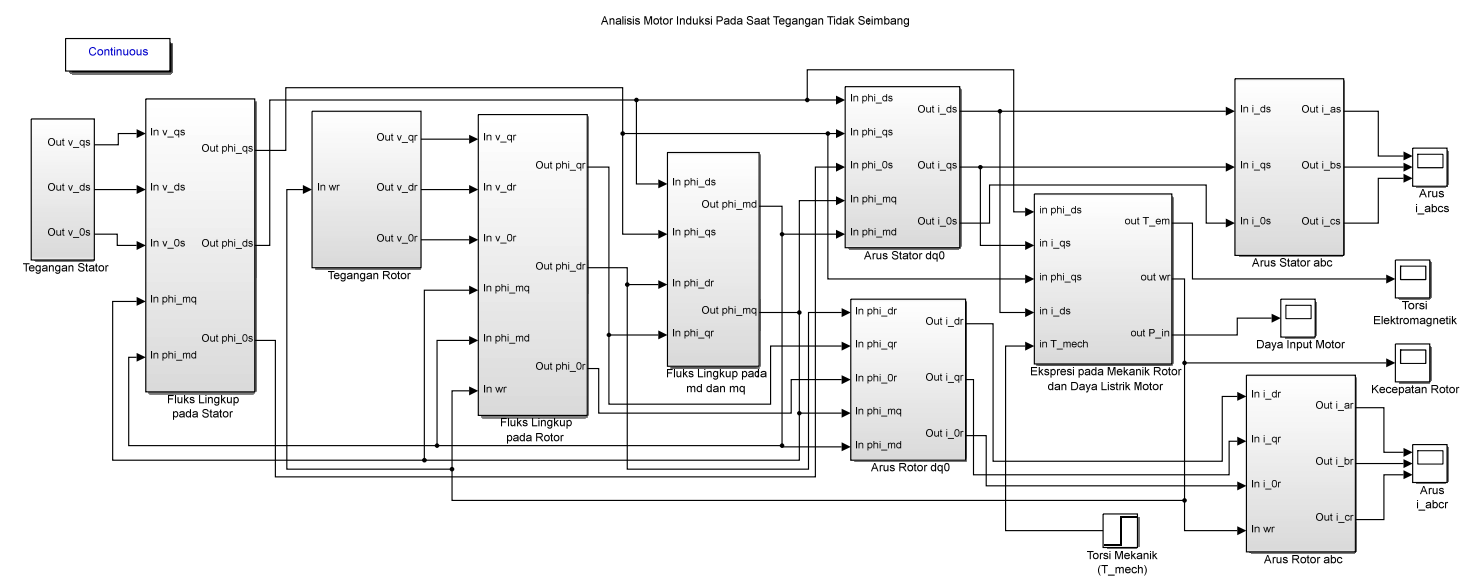

Gambar 6. Pemodelan Motor Induksi Tiga Fasa

\subsection{Hasil dan Pembahasan}

Untuk inisialisasi model simulasi, digunakan motor induksi tiga fasa dengan mengikuti spesifikasi sebagai berikut [13]:

$\begin{array}{cccc}\text { Power: } 5 \mathrm{Hp} & \text { Frekuensi: } 60 \mathrm{~Hz} & \text { Jumlah kutub: } 4 & \text { Tegangan: } 220 \text { Volt } \\ r_{s}=0,531 \Omega & r_{r}^{\prime}=0,408 \Omega & X_{l s}=X^{\prime}{ }_{l r}=0,95 \Omega & X_{M}=31,95 \Omega\end{array}$

\subsubsection{Karakteristik Tegangan Stator}

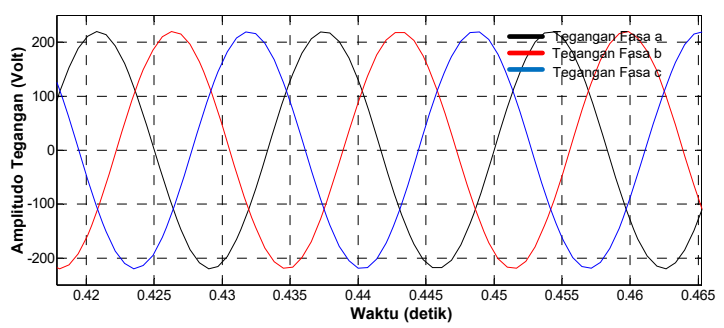

Gambar 7. Tegangan Tiga Fasa $a b c$

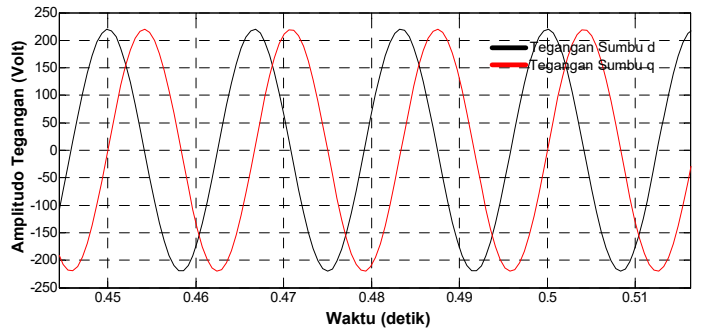

Gambar 8. Tegangan Dua Fasa $d q$

Tegangan input dari pemodelan motor induksi tiga fasa adalah tegangan tiga fasa. Untuk dapat mempermudah analisis kinerja motor induksi tersebut maka diperlukan pemodelan dinamik dengan menggunakan pemodelan kerangka acuan atau metode 
transformasi $d q 0$. Pemodelan dinamik ini dibentuk dari transformasi tegangan tiga fasa $a b c$ $\left(\angle 120^{\circ}\right)$ menjadi tegangan dua fasa $d q\left(\angle 90^{\circ}\right)$.

\subsubsection{Karakteristik Arus Stator dan Arus Rotor}

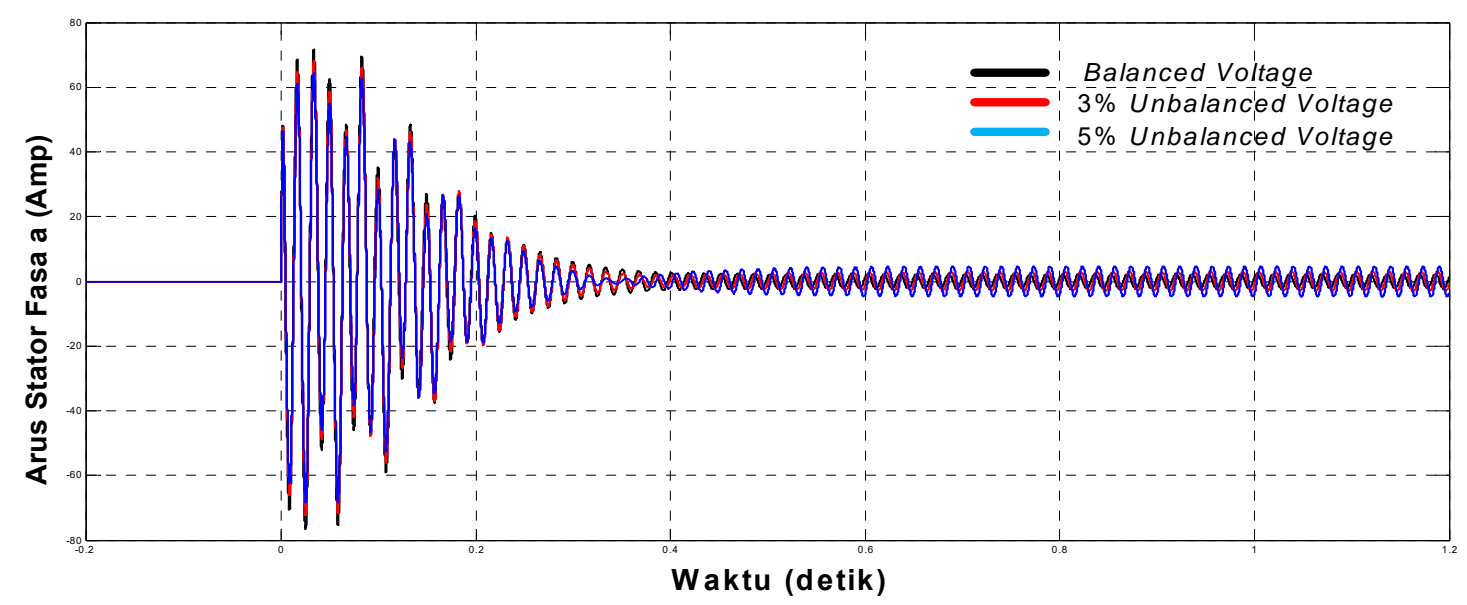

Gambar 9. Grafik Karakteristik Arus Keluaran Stator Tiga Fasa

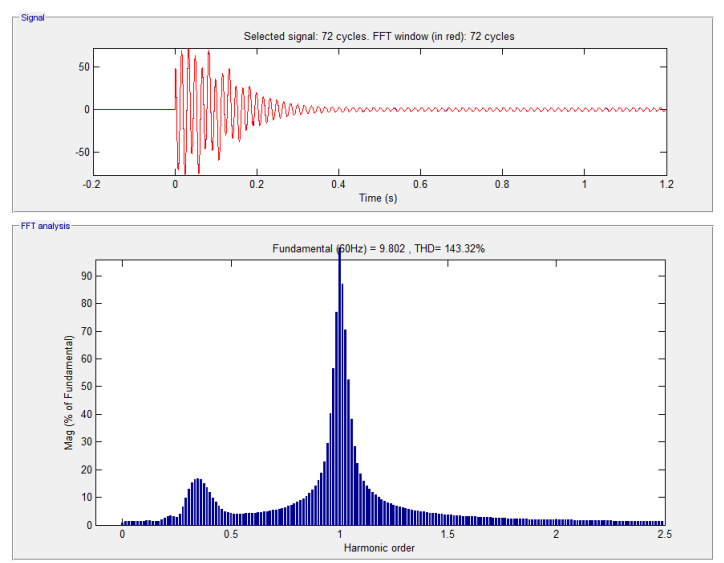

Gambar 10. Total Harmonik Distorsi Arus Stator saat Tegangan Seimbang

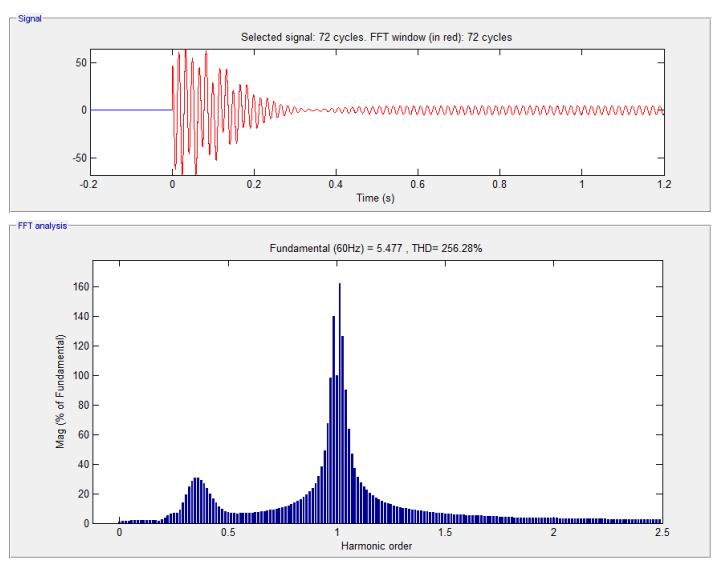

Gambar 11. Total Harmonik Distorsi Arus Stator saat 5\% Unbalanced Voltage

Gambar 9, 10, dan 11, memperlihatkan karakteristik arus stator motor induksi pada saat pengasutan sampai dengan pada saat kondisi steady state. Pada saat keadaan tegangan seimbang, ketiga arus stator mempunyai nilai maksimum sebesar 69,2 Ampere dengan rentang waktu sebesar 0,37 detik untuk mencapai keadaan steady state sebesar 2,4 Ampere. Tetapi pada saat terjadi keadaan tegangan tidak seimbang sebesar $1 \%$, sampai dengan $5 \%$, arus stator pada salah satu fasa (fasa a) mengalami kenaikan nilai amplitudo sebesar 3,1 Ampere sampai dengan 8,3 Ampere atau mengalami kenaikan sebesar 29,1\% sampai dengan $245,8 \%$. Dan pada arus stator fasa yang lain (fasa $c$ ) terjadi penurunan nilai arus sebesar 0,1 Ampere sampai dengan 0,7 Ampere, sehingga hal ini dapat dikatakan bahwa terjadi arus pembebanan yang tidak seimbang diantara ketiga fasa pada saat tegangan tidak seimbang. Untuk lebih jelasnya hal ini dapat dilihat pada Gambar 12. 

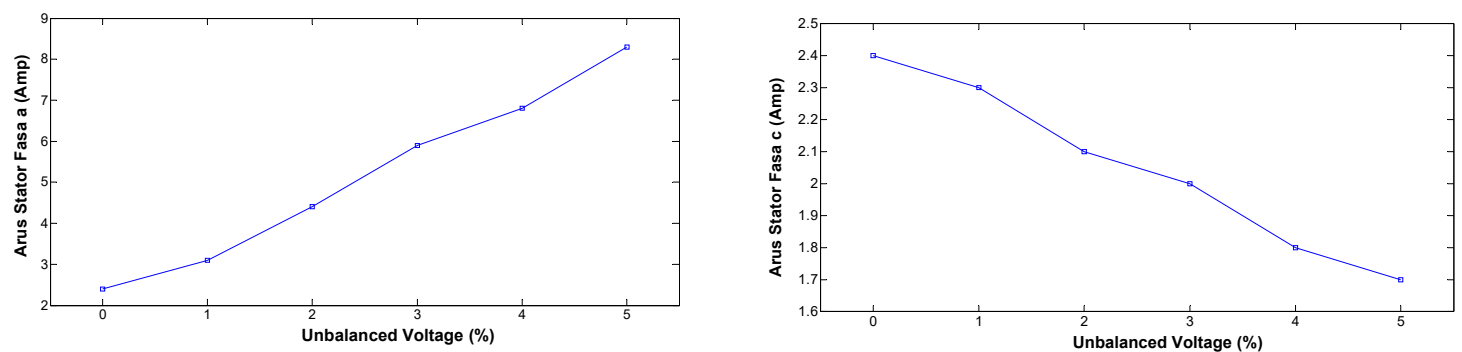

Gambar 12. Karakteristik Arus Stator Fasa $a$ dan Fasa $c$ saat Terjadi Ketidakseimbangan Tegangan

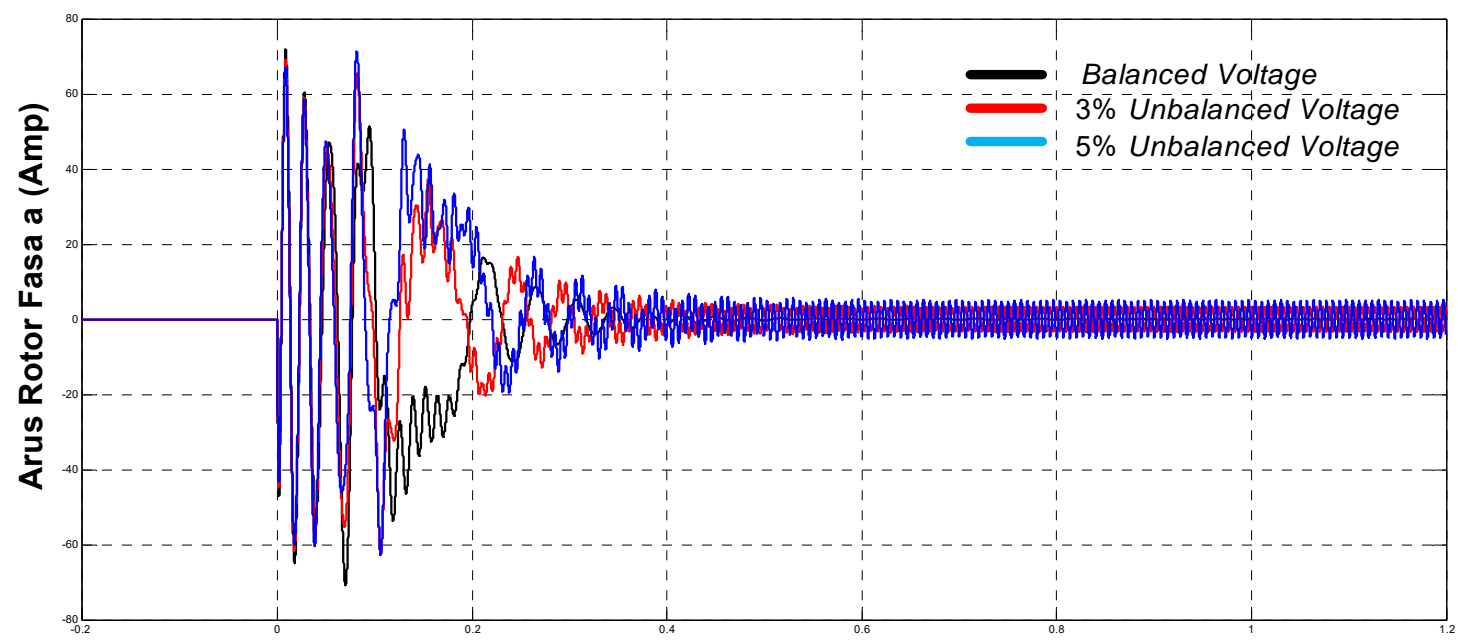

Waktu (detik)

Gambar 13. Grafik Karakteristik Arus Keluaran Rotor Tiga Fasa

Gambar 13, 14, dan 15, memperlihatkan karakteristik arus rotor motor induksi pada saat pengasutan sampai dengan pada saat kondisi steady state. Pada saat keadaan tegangan seimbang, ketiga arus rotor mempunyai nilai maksimum sebesar 68,7 Ampere dengan rentang waktu sebesar 0,37 detik untuk mencapai keadaan steady state sebesar 1,4 Ampere. Tetapi pada saat terjadi keadaan tegangan tidak seimbang sebesar $1 \%$, sampai dengan $5 \%$, arus rotor pada ketiga fasa tersebut mengalami kenaikan nilai amplitudo sebesar 3,3 Ampere sampai dengan 6,7 Ampere atau mengalami kenaikan sebesar 135,7\% sampai dengan $378,6 \%$. Fenomena lain yang terjadi pada arus rotor saat tegangan tidak seimbang adalah terdapatnya osilasi gelombang pada arus dan distorsi harmonik. Distorsi harmonik ini mengalami kenaikan sebesar $48,9 \%$ saat ketidakseimbangan tegangan terjadi sebesar $5 \%$. Efek dari timbulnya osilasi gelombang dan distorsi harmonik inilah yang dapat menimbulkan efek pemanasan pada rotor motor induksi selain kenaikan arus rotor. 


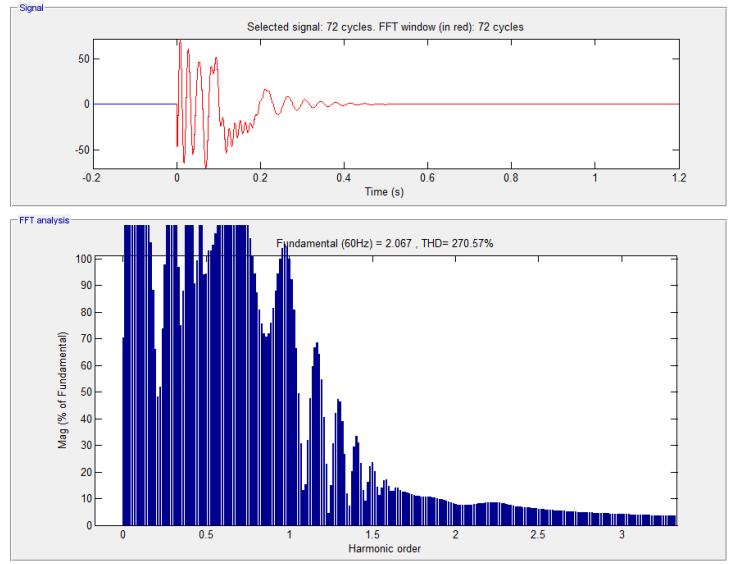

Gambar 14. Total Harmonik Distorsi Arus Rotor saat Tegangan Seimbang
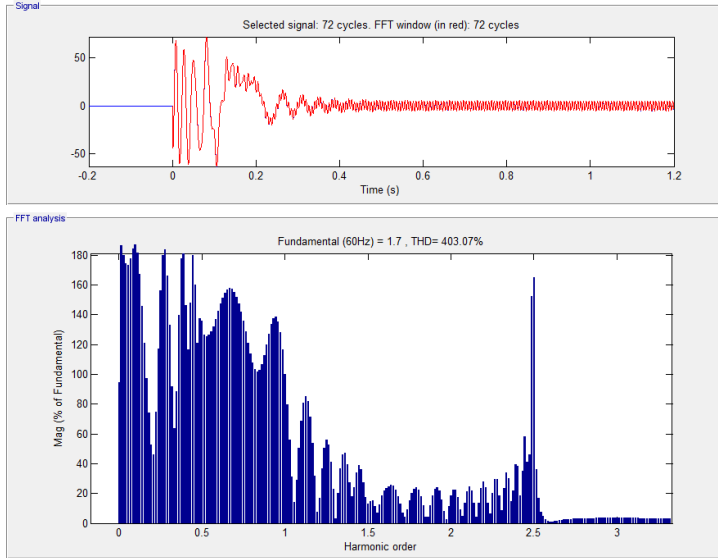

Gambar 15. Total Harmonik Distorsi Arus Rotor saat 5\% Unbalanced Voltage

3.2.3 Karakteristik Torsi Elektromagnetik dan Kecepatan Putaran Rotor

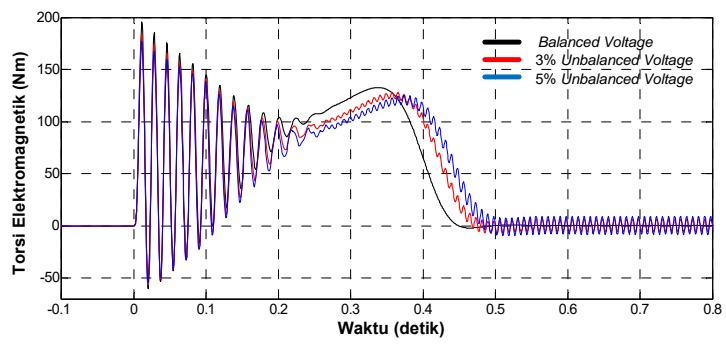

Gambar 16. Grafik Karakteristik

Torsi Eelektromagnetik terhadap Waktu

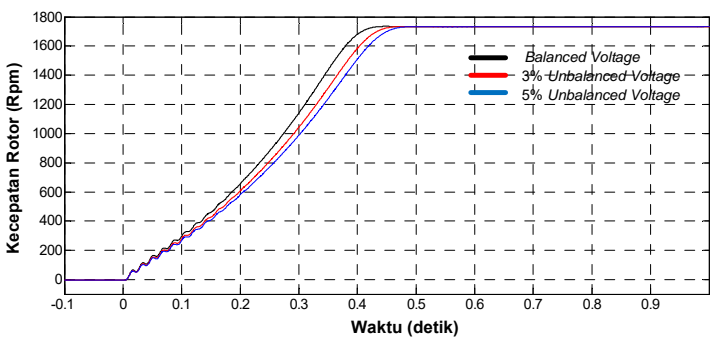

Gambar 17. Grafik Karakteristik

Kecepatan Rotor terhadap Waktu

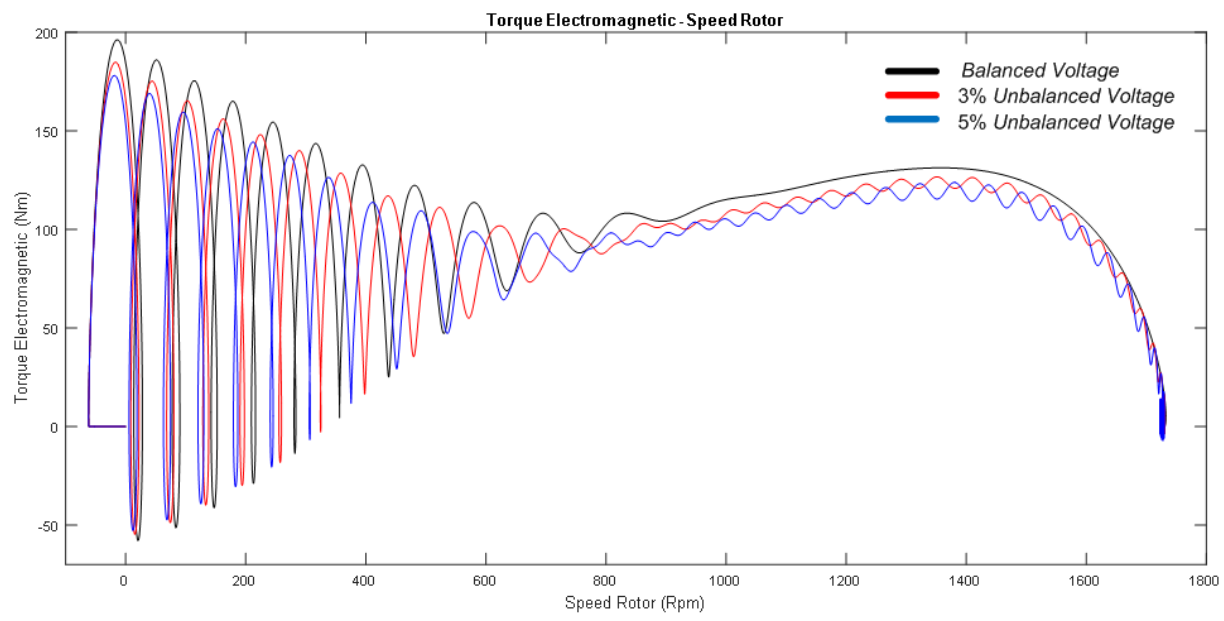

Gambar 18. Grafik Karakteristik

Torsi Elektromagnetik terhadap Kecepatan Rotor

Gambar 16 dan Gambar 18, memperlihatkan karakteristik torsi elektromagnetik motor induksi pada saat pengasutan sampai dengan kondisi steady state. Pada gambar tersebut torsi elektromagnetik mengalami kenaikan sampai pada keadaan nilai maksimum dan kemudian turun sampai pada keadaan steady state. Hal ini seiring dengan kecepatan putaran rotor, dimana karakteristik kecepatan putaran rotor mempunyai karakteristik yang sama dengan torsi elektromagnetik. Pada saat keadaan tegangan seimbang, torsi elektromagnetik mempunyai nilai maksimum sebesar $136,3 \mathrm{Nm}$ dengan rentang waktu sebesar 0,37 detik 
untuk mencapai keadaan steady state. Tetapi pada saat keadaan tegangan tidak seimbang sebesar $1 \%$, sampai dengan $5 \%$, torsi elektromagnetik mengalami penurunan nilai maksimum sebesar 3,95 $\mathrm{Nm}$ sampai dengan 18,85 $\mathrm{Nm}$ dan mengalami rentang waktu yang lebih lama untuk mencapai keadaan staedy state sebesar 0,01 detik sampai dengan 0,02 detik, dan untuk lebih jelasnya hal ini dapat dilihat pada Gambar 19. Pada Gambar 17 dan Gambar 18, memperlihatkan karakteristik kecepatan putaran rotor pada saat pengasutan sampai dengan keadaan staedy state. Pada keadaan tegangan seimbang, kecepatan putaran rotor mempunyai nilai sebesar 1727,4 Rpm dengan rentang waktu sebesar 0,37 detik untuk mencapai keadaan steady state. Tetapi pada saat keadaan tegangan tidak seimbang sebesar $1 \%$, sampai dengan $5 \%$, kecepatan putaran rotor mengalami penurunan nilai sebesar $1 \mathrm{Rpm}$ sampai dengan 6,6 Rpm dan mengalami rentang waktu yang lebih lama untuk mencapai keadaan staedy state sebesar 0,01 detik sampai dengan 0,02 detik, dan untuk lebih jelasnya hal ini dapat dilihat pada Gambar 20.

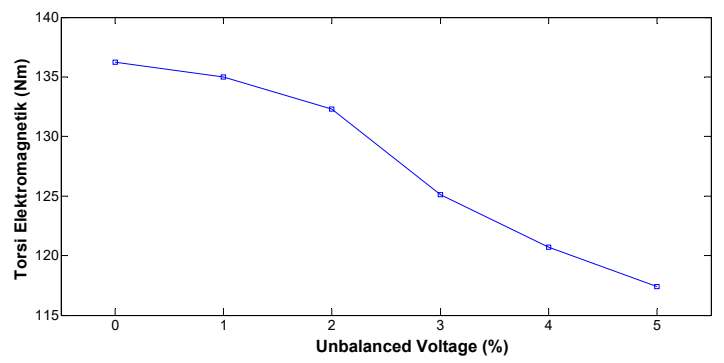

Gambar 19. Karakteristik Torsi

Elektromagnetik terhadap

Ketidakseimbangan Tegangan

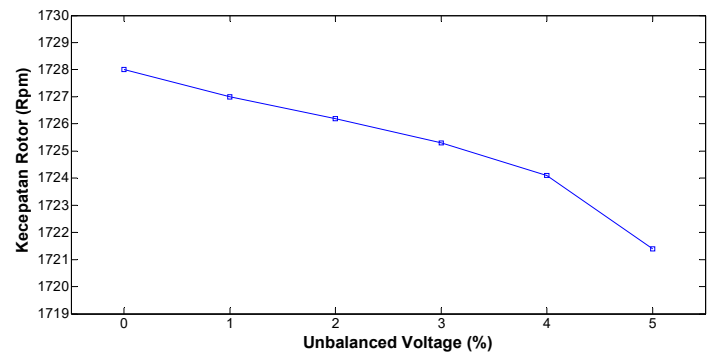

Gambar 20. Karakteristik Kecepatan Rotor terhadap Ketidakseimbangan Tegangan

\subsubsection{Karakteristik Daya Masukan dan Daya Keluaran Motor}

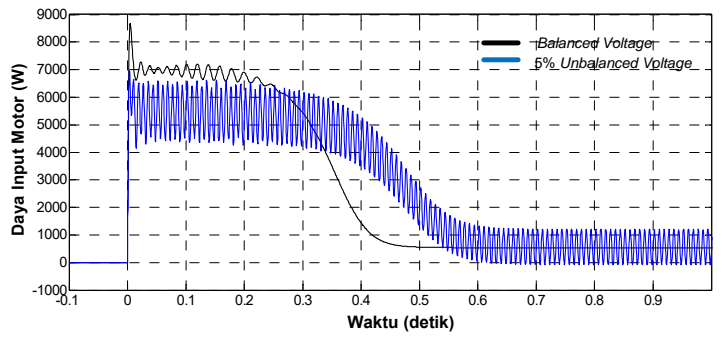

Gambar 21. Karakteristik Daya Input terhadap Waktu

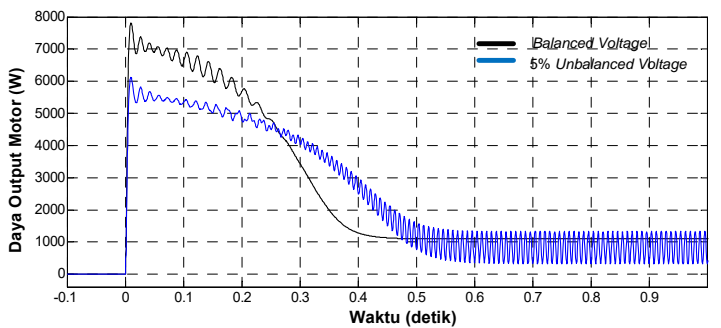

Gambar 22. Karakteristik Daya Output terhadap Waktu

Gambar 21 dan Gambar 22, memperlihatkan karakteristik daya pada motor induksi. Pada saat keadaan tegangan seimbang, daya input motor (Gambar 21) mempunyai nilai maksimum sebesar 8,76 Kw. Tetapi pada saat terjadi keadaan tegangan tidak seimbang sebesar $1 \%$, sampai dengan $5 \%$, daya input maksimum pada motor tersebut mengalami penurunan nilai sebesar $1,23 \mathrm{Kw}$ sampai dengan $6,97 \mathrm{Kw}$ atau mengalami penurunan sebesar 16,33\% sampai dengan 25,68\%. Untuk daya output motor (Gambar 22) mempunyai nilai maksimum sebesar 7,46 Kw. Tetapi pada saat terjadi keadaan tegangan tidak seimbang sebesar $1 \%$, sampai dengan $5 \%$, daya input maksimum pada motor tersebut mengalami penurunan nilai sebesar $930 \mathrm{w}$ sampai dengan $6,14 \mathrm{Kw}$ atau mengalami penurunan sebesar 14,24\% sampai dengan 21,5\%. Dari hasil daya input dan daya output motor, maka didapatkan nilai efisiensi motor yang mengalami penurunan antara 89,35\% sampai 87,42\% (Gambar 23). 


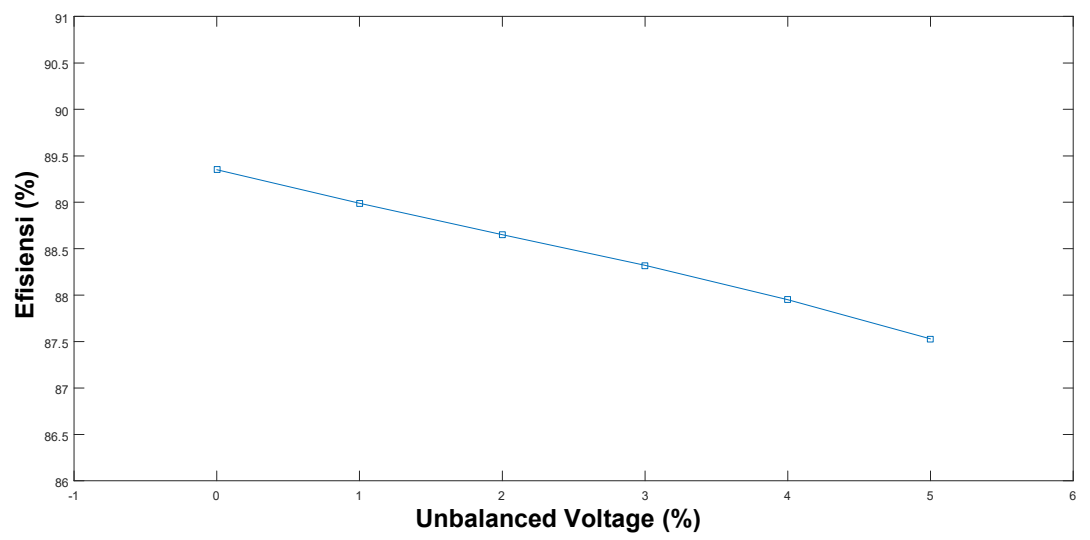

Gambar 23. Efisiensi motor terhadap Ketidakseimbangan Tegangan

\section{Kesimpulan}

Pada makalah pengaruh kinerja motor induksi pada tegangan tak seimbang dengan metode transformasi direct qudrature dapat disimpulkan beberapa hal sebagai berikut:

1. Implementasi dan pemodelan dinamik dari motor induksi tiga fasa menggunakan Matlab/Simulink disajikan secara bertahap. Simulasi pemodelan kinerja motor induksi dengan metode kerangka acuan telah memberikan respons yang memuaskan, dalam hal dapat menganalisis karakteristik torsi elektromagnetik, kecepatan putaran rotor, arus stator, arus rotor, dan daya motor.

2. Pada saat terjadi ketidakseimbangan tegangan mencapai $5 \%$, karakteristik arus stator pada salah satu fasa dapat mengalami kenaikan hingga 245,8\%. Hal ini dapat mengakibatkan efek pemanasan yang tidak merata pada ketiga fasa tersebut.

3. Pada karakteristik torsi elektromagnetik dan arus rotor, terdapat fenomena osilasi gelombang yang semakin besar jika terjadi ketidakseimbangan tegangan yang semakin besar. Hal ini dapat mengakibatkan terjadinya getaran pada motor yang semakin besar, sehingga NEMA membatasi untuk pengoperasian motor induksi tidak boleh melampaui $5 \%$ dari nilai ketidakseimbangan tegangan.

\section{Daftar Pustaka}

[1] Mirabbasi, D., Seifossadat, G., \& Heidari, M. (2009, November). Effect of unbalanced voltage on operation of induction motors and its detection. In 2009 International Conference on Electrical and Electronics Engineering-ELECO 2009 (pp. I-189). IEEE.

[2] Ansari, A. A., \& Deshpande, D. M. (2009, July). Investigation of performance of 3phase asnchronous machine under voltage unbalance. In Journal of Theoretical and applied information Technology.

[3] Aderibigbe, A., Ogunjuyigbe, A., Ayodele, R., \& Samuel, I. (2017). The performance of a 3-phase induction machine under unbalance voltage regime. Journal of Engineering Science and Technology Review, 10(5), 136-143.

[4] Pillay, P., \& Manyage, M. (2001). Definitions of voltage unbalance. IEEE Power Engineering Review, 21(5), 50-51.

[5] Lee, R. J., Pillay, P., \& Harley, R. G. (1984). D, Q reference frames for the simulation of induction motors. Electric power systems research, 8(1), 15-26.

[6] Shah, S., Rashid, A., \& Bhatti, M. K. L. (2012). Direct quadrate (dq) modeling of 3phase induction motor using matlab/simulink. Canadian Journal on Electrical and Electronics Engineering, 3(5), 237-243.

[7] Bellure, A., \& Aspalli, M. S. (2015). Dynamic dq model of Induction Motor using 
Simulink. International Journal of Engineering Trends and Technology (IJETT), 24(5), 252-257.

[8] Patel, H. K. (2009). Steady state and transient performance analysis of three phase induction machine using MATLAB simulations. International Journal of Recent Trends in Engineering, 1(3), 266.

[9] Kamal, A., \& Giri, V. K. (2013). Mathematical modelling of dynamic induction motor and performance analysis with bearing fault. International Journal of Innovative Technology and Research, 1(4), 336-340.

[10] Deb, P. B., \& Sarkar, S. (2016). Dynamic model analysis of three phase induction motor using Matlab/Simulink. International Journal of Scientific \& Engineering Research, 7(3), 572.

[11] Ratnani, P. L., \& Thosar, A. G. (2014). Mathematical Modelling of an 3 Phase Induction Motor Using MATLAB/Simulink. International Journal Of Modern Engineering Research (IJMER), 4(6), 62-67.

[12] Sarma Sunilkumar, M., \& Patel, A. T. (2016). Mathematical Modelling of an 3 Phase Induction Motor Using MATLAB/Simulink.

[13] Krause, P. C., Wasynczuk, O., Sudhoff, S. D., \& Pekarek, S. (2002). Analysis of electric machinery and drive systems (Vol. 2). New York: IEEE press.

[14] Krishnan, R. (2001). Electric motor drives: modeling, analysis and control. Prentice Hall.

\section{Tata Nama}

$\begin{array}{ll}H & \text { inertia constant } \\ i_{d s}, v_{d s} & \text { stator d-axis current dan voltage } \\ i_{d r}, v_{d r} & \text { rotor d-axis current dan voltage } \\ i_{q s}, v_{q s} & \text { stator q-axis current dan voltage } \\ i_{q r}, v_{q r} & \text { rotor q-axis current dan voltage } \\ J & \text { inertia of motor } \\ L_{l s} & \text { stator self inductance } \\ L_{l r}^{\prime} & \text { rotor self inductance } \\ L_{M} & \text { mutual inductance } \\ P & \text { number of poles } \\ p & \text { derivative operator } \frac{d}{d t}\end{array}$

$\begin{array}{ll}r_{s} & \text { stator resistance } \\ r_{r}^{\prime} & \text { rotor resistance } \\ T_{e} & \text { torque electromagnetic } \\ T_{L} & \text { load torque } \\ X_{l s} & \text { stator leakage reactance } \\ X^{\prime}{ }_{l r} & \text { rotor leakage reactance } \\ X_{M} & \text { magnetizing reactance } \\ \lambda, \psi & \text { flux linkage } \\ \omega_{b} & \text { nominal speed } \mathrm{rad} / \mathrm{sec} \\ \omega_{r} & \text { rotor speed } \mathrm{rad} / \mathrm{sec}\end{array}$

